\title{
A Study of Needle Stick Injury among the Nursing Staff in a 300 Bedded Pediatric Specialized Centre of a 2000 Bedded Teaching Hospital Services
}

\author{
Ashok Kumar, Yatin Talwar* and Ranjana Singh \\ Department of Hospital Administration, India
}

Submission: December 15, 2017; Published: February 02, 2018

"Corresponding author: Yatin Talwar, Department of Hospital Administration, India, Email: drtalwaryatin@gmail.com

Abstract

Needle-stick injuries (NSI) pose one of the common occupational health hazards in a health care setting. Though preventable, they are usually dealt covertly, thereby are less reported. The Aim of this study was to determine prevalence, incidence of NSI, and also to identify the situations which increases the NSI.

Keywords: Needle stick injury, Hospital worker safety

\section{Introduction}

Health provider's especially nursing staffs are always exposed to an increased risk of Needle stick (NSI) injury due to their exposure to highly competitive work environment and work related stress.This also exposes them to enhanced risk of diseases transmitted by blood which include Hepatitis B - C, HIV, TB and many others. The documented risk percentage of HIV transmission after percutaneous exposure to HIV-infected blood in a health care professional has been estimated as 3 in 1000 $[1,2]$. As per the WHO study, the estimated proportions of health care professionals/providers exposed to blood-borne pathogens globally were $2.6 \%$ for HCV, $5.9 \%$ for HBV, and $0.5 \%$ for HIV, corresponding to about $16,000 \mathrm{HCV}$ infections and 66,000 HBV infections in HCW worldwide [3].

Due to underreporting, the documented injury rate is always low and hence the low injury rates cannot be correlated with the actual NSI incidence. In many developed countries real time injury monitoring superadded with Standard operating protocols and stringent, accurate reporting systems actually have reported NSI as high as 10 times of the prevalent documented rates [4]. The serious threat by these NSI undoubtedly cause serious health crisis with risk of further transmission thus jeopardizing the health cover, superadded with emotional mayhem and instability which results in loss from work. Thus these NSI have a direct and indirect consequence in the health care setup which are significant especially in developing countries. Also the healthcare providers are themselves limited in numbers with respect to the overall burden of disease in developing countries, loss of days' work can further jeopardize the existing fragile healthcare system. The study addresses the issue of NSI at a super-specialty pediatrics tertiary care center of North India, the study was done with an aim to correlate meaningful association of NSI with stress, years of experience, role of education in reducing NSI and creating further awareness about NSI.

\section{Material and Methods}

\section{Study design: Cross-sectional study}

Design Setting-A Quantitative study design was chosen. The study was kept contextual, as only nursing staff working at advanced pediatric centre was used.

Defination of NSI-The definition of NSI was based on CDC and WHO definition of "any cut or prick to the participants by any type of sharp/discarded /partially destroyed needle previously used earlier and within the premises of the hospital."

Permission and ethic clearance- Permission and ethic clearance was also taken in advance. Participant Population and sampling Methods. The study population included the nursing 
staff working in a 300 bedded pediatrics superspeciality center of a 2000 bedded tertiary care teaching hospital $(n=250)$. All of the nursing staff was included in the study therefore no purposive sampling was done .Out of 250 people who were approached for the study, 235 members agreed for the study. There were 15 dropouts.

\section{Data treatment}

A semi open pretested questionnaire/ instrument was developed in consultation with department of hospital administration and Microbiology. The instrument was developed on basis of designation of nursing staff and years of experience , area of work , qualifications , knowledge about PEP and needle stick injury with due consideration given to training received. The questionnaire had four parts: incidence of NSIs in a year, characteristics of nurse, knowledge with NSI and management done post NSI.

\section{Data collection}

The questionnaires/Data collection tool was distributed amongst all 250 nursing staff. The data tool was given to the staff attending duty in their respective shifts. After completion, the completed questionnaire were collected and returned immediately to the principal investigator. Incomplete forms were also taken as dropouts. Hence Completed questionnaires were 229 in number. $(n=229 / 250=91.6 \%)$.

Data collection involved simple interview technique using a mixed (semi open) type of data collection tool/ questionnaire that was supposed to be completed by all study subjects of a particular shift at a pre-defined single time slot. This was done with a preliminary aim to obtain actual opinions without any bias. Nursing staff on Post duty off were given the questionnaire next day and completed forms were collected at that instant only. All these measures were taken to avoid bias and any kind of discrepancy.

Also at no point investigator and participants were allowed any discussion whatsoever, this was primarily done to eliminate investigator bias. All subjects were contacted in person, were told about purpose of study and were also informed that the responses shall be kept anonymous. Informed consent was taken from each participant before filling the questionnaire [5].

A. Inclusion criteria-All nursing personnel staff providing healthcare services to patients in the study area.

B. Exclusion criteria-Refusal to participate in the study.

C. Data Analysis-Data was collected. SPSS was used to draw inferences. Statistical test were applied including Chi-square for associations and significance.

\section{Significance of the Study}

The complimentary roles and functions of knowledge, attitude, and continued nursing education in a clinical setting is the significance of the study. The long term goal of creation of awareness on dangers of a needle stick injury with abolition of social stigmas in reporting, also inculcating safe practices with need for continued medical education will be demonstrated. Thus by this study we also plan to create further awareness on dangers of needle-stick injury and enhanced safe practices thereby eliminating dangers in transmitting blood borne infection

\section{Results}

\section{Characteristics of the study hospital and nursing staff}

The total nursing staff allocated to the hospital is 250 . Thus ratio Bed Per nursing staff works out to be 1.2. The respondents (Nursing staff) consisted of 1 DNS (deputy nursing superintendent), 10 ANS (assistant nursing superintendent), and 55 GR 1 (Grade 1) Nursing staff, rest all nursing staff beingGR-2 (Grade 2 staff).

\section{Response rate}

Out of total sanctioned strength of 250 nurses, 229, thereby a response of $91.6 \%$ was seen. Majority of respondents were females $(68.3 \%)$ and their mean age was $32(\mathrm{SD}=8.0)$ years old, also the difference in mean-ages was significant statistically $(\mathrm{P}<$ 0.05). Frequency of nursing staff as per their years of work in the institution was also compiled. The majority of them, 187 out of 250 respondents, had work experience less than ten years (75\%).

\section{Major Cause of Injury}

Recapping of needles (40\%) proved the most common and dangerous procedure leading to injury in our study. Other significant number of injuries happened during disposal, Drawing up samples for blood investigations, and others procedures like IV lines setup and injections.

\section{Prevalence of NSI amongst Nurses}

Table 1: The likely hood of a person not getting a NSI was also calculated .which came out to be $55 \%$.

\begin{tabular}{|c|c|c|c|}
\hline & Value & df & Asymp. Sig .(2 Sided) \\
\hline Pearson Chi-Squarea & 44.12 & 36 & 0.166 \\
\hline Likelihood Ratio & 54.733 & 36 & 0.023 \\
\hline $\begin{array}{c}\text { Linear by Linear } \\
\text { Association }\end{array}$ & 16.962 & 1 & 0 \\
\hline N of Valid Cases & 229 & & \\
\hline
\end{tabular}

a.63 cells (85.1\%) have expected count lessthan 5. The minimum expected count is 0.23 .

The frequency of NSI was found to be $55.46 \%$ ( $\mathrm{n} 1=127)$. Table 1 presents the frequency of NSI amongst healthcare workers in a year. $42.52 \%(n 2=54)$ of respondents had one episode of NSI. $15.75 \%(n 3=20)$ had two episodes of NSI, 19.69 $\%(n 4=25)$ of the study population had more than two episodes of NSI. A fourth category of people $22.05 \%$ (n5=28) was seen who were not able to recall the number of times they suffered an injury (Figure 1). 


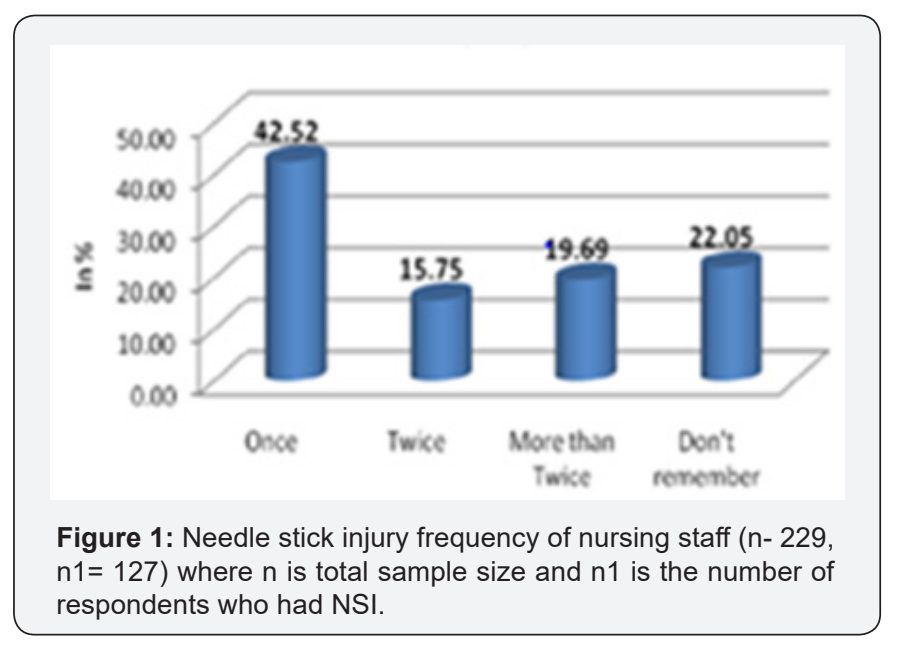

Reporting of NSI Within 30 Minutes of the Injury

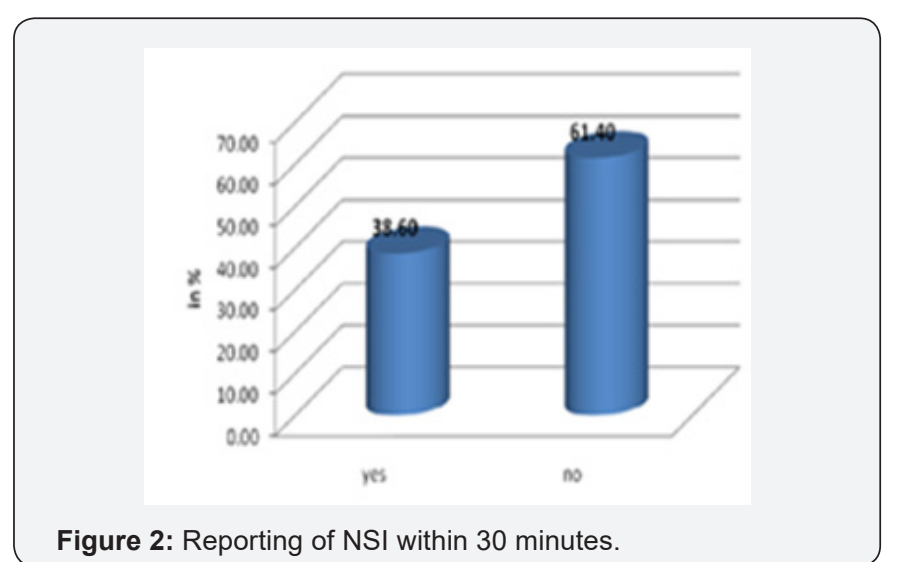

Figure 2 presents number of respondents who had reported the NSI within 30 minutes. Out of the total sample (n1=127) who had suffered a NSI $38.58 \%$ (n6= 49) of respondents with NSI ( $\mathrm{n} 1=127)$ reported it immediately (within 30 minutes).

\section{Reason for quick reporting (within 30 minutes)}

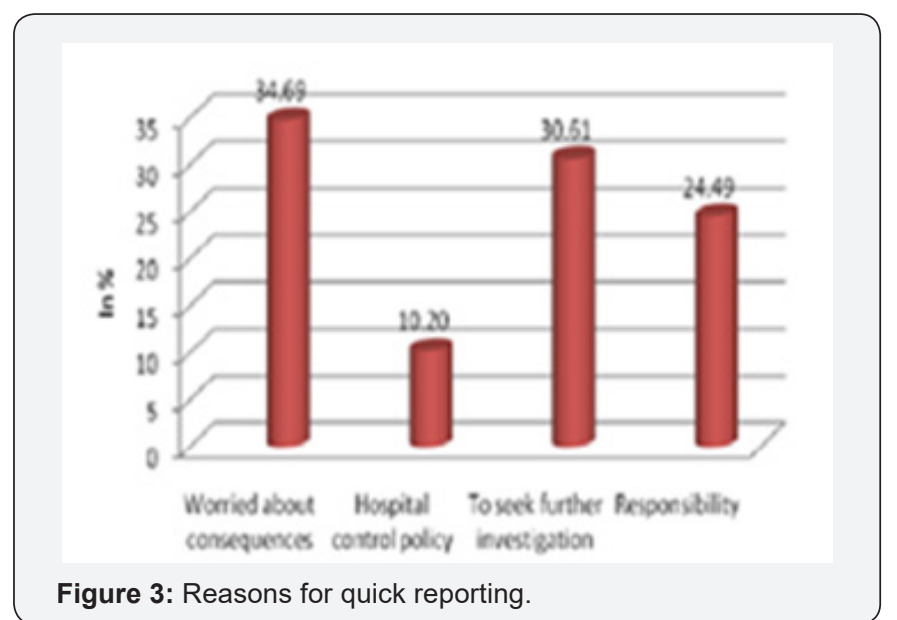

Figure 2.1 shows the reason cited for quick reporting of a NSI. Majority of Nursing staff $34.60 \%(n 7=17, n 1=127)$ cited information about risk factors associated with NSI and further consequences related with NSI lead them to quickly report a
NSI. $30.61 \%(n 8=15, \mathrm{n} 1=127)$ reported NSI for getting further investigations done. $10.20 \%(n 9=5, n 1=127)$ had reported NSI as they felt it's important to report it under hospital infection control guideline. $24.49 \%(\mathrm{n} 10=12, \mathrm{n}=127)$ responders felt that it was their responsibility to report NSI (Figure 3).

\section{Causative factors associated with NSI}

The result of this correlation has been depicted in Figure 3. Association of NSI was found to be maximum with stress and patient overload (47\%), and (27.5\%) NSI were contributed by lack of use of protective measures taken by respondent himself /herself and inattention as a cause. Years of experience and NSI were also correlated and it was found that, the risk for NSI significantly decreased as the experience increased (OR $=0.990$, $\mathrm{CI}=0.979-0.992$ ) (Figure $4 \&$ Table 1 ).

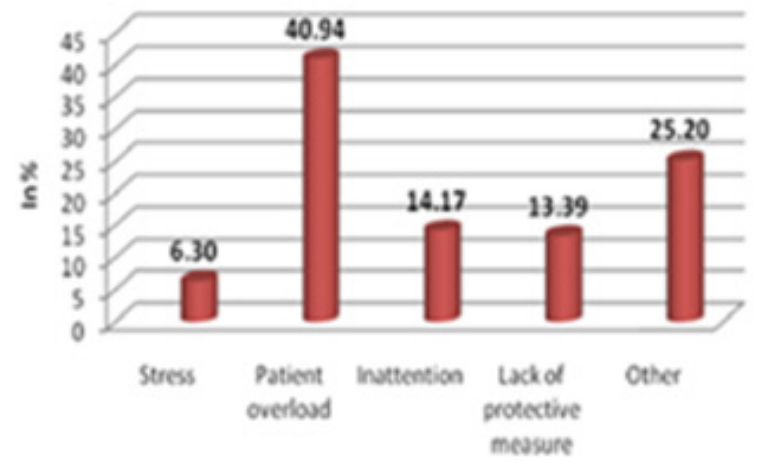

Figure 4: Reasons for NSI.

\section{Interpretations and Comparisons}

Response rate - The response rate in previously done study in previous study 6 was $89.76 \%$. This improved percentage obtained in present study might be due to better awareness about needle stick injury due to repeated orientation programmers 'in the Institute [6].

Major Cause Of Injury - The percentage of NSI due to recapping in previous study 6,7 (39\%) and (66.3\%) respectively, with respect to $40 \%$ in our study. Frequency of NSI , Reporting of NSI, We believe, perhaps it's the first study in the country where these subtopics were researched. A lacunae exists in other studies in these regard so comparison was not possible.

\section{Conclusion}

NSI is an important acquired occupational health hazard; the best possible way to reduce is by conducting regular interaction, classes and orientation programs with the Health care professionals. Efforts have resulted in little superior results but there are still much to be achieved. Besides emphasizing NSI only, the onus has now shifted also on to early and centpercent reporting, early diagnosis, completion of PEP and better Counseling and psychological support. Efforts by all Stake holders in unison collectively need to be taken to efficiently tackle this 
menace. Needle stick and damage done to the healthcare cannot be completely eradicated but can be reduced $[7,8]$.

\section{References}

1. Gerberding JL (1994) Incidence and prevalence of human immunodeficiency virus, hepatitis B virus, hepatitis C virus, and cytomegalovirus among health care personnel at risk for blood exposure: Final report from a longitudinal study. J Infect Dis 170: 14101417.

2. Tokars JI, Marcus R, Culver DH, Schable CA, McKibben PS, et al. (1993) Surveillance of HIV infection and zidovudine use among health care workers after occupational exposure to HIV-infected blood. Ann Intern Med 118(12): 913-919.

3. Pruss-Ustun A, Rapiti E, Hutin Y (2003) Sharps injuries: Global burden of disease from sharps injuries to health-care workers. World Health Organization. Geneva, Switzerland.
4. Elder A, Paterson C (2006) Sharps injuries in UK health care: A review of injury rates, viral transmission and potential efficacy of safety devices. Occup Med 56: 566-574.

5. Kermode M, Jolley D, Langkham B, Thomas MS, Crofts N (2005) Occupational exposure to blood and risk of bloodborne virus infection among health care workers in rural north Indian health care settings. Am J Infect Control 33(1): 34-41.

6. Singru SA, Banerjee A (2008) Occupational exposure to blood and body fluids among health care workers in a teaching hospital in Mumbai, India. Indian J Community Med 33(1): 26-30.

7. Muralidhar S, Singh PK, Jain RK, Malhotra M, Bala M (2010) Needle stick injuries among health care workers in a tertiary care hospital of India. Indian J Med Res 131: 405-410.

8. Munish A, Vikas B, Sonia P, Meenal T, Vipin K (2011) Needle stick injury and HIV risk among health care workers in North India. Indian J Med Sci 65(9): 371-378.

Your next submission with JuniperPublishers will reach you the below assets

- Quality Editorial service

- Swift Peer Review

- Reprints availability

- E-prints Service

- Manuscript Podcast for convenient understanding

- Global attainment for your research

- Manuscript accessibility in different formats

( Pdf, E-pub, Full Text, audio)

- Unceasing customer service

Track the below URL for one-step submission https://juniperpublishers.com/online-submission.php 